\title{
Pityriasis rubra pilaris post-infection due COVID-19: case report
}

\section{Pitiriasis rubra pilaris post-infección por COVID-19: reporte de un caso}

\author{
Franklin R Aguilar-Gamboa' ${ }^{(D e n n i s ~ C u b a s-A l a r c o n}{ }^{2}$ (D) Miguel Villegas-Chiroque ${ }^{3}$ \\ and Virgilio E Failoc-Rojas ${ }^{4}$ \\ virgiliofr@gmail.com
}

1 Hospital Regional Lambayeque, Laboratorio de inmunología y virología, Dirección de Investigación. Chiclayo, Perú. 2 Hospital Regional Docente Belén de Lambayeque, Laboratorio de Microbiología, Servicio de Laboratorio Clínico, Belén de Lambayeque, Perú. 3 Hospital Regional Lambayeque, Servicio de Infectología, Chiclayo, Perú. 4 Universidad San Ignacio de Loyola, Lima, Perú.

\begin{abstract}
Citation: Aguilar-Gamboa FR, Cubas-Alarcon D, Villegas-Chiroque M, Failoc-RojasVE. Pityriasis rubra pilaris post-infection due COVID-19: case report Colomb Med (Cali).

2021; 52(1):e7014577 http://doi. org/10.25100/cm.v52i1 4577
\end{abstract}

\footnotetext{
Received : 10 Oct 2020

Revised: 03 Feb 2021

Accepted : 11 Mar 2021

Published: 18 Mar 2021
}

Keywords:

SARS-CoV-2; COVID-19; pityriasis rubra pilaris; dermatology; exanthema; urticaria; pruritus; eczema; erythema multiforme; keratoderma palmoplantar.

Palabras clave:

SARS-CoV-2; COVID-19; pititriasis rubra pilaris; dermatología; Exantema; Urticaria; Prurito; Eczema; Eritema multiforme; Queratodermia palmoplantar.

Copyright: @ 2021 Universidad del Valle.

(c) (1) 8

\section{Abstract}

\section{Case description:}

32-month-old boy, IgG positive for SARS-CoV-2, presented to the emergency department with dermatologic lesions.

\section{Clinical findings:}

Four days before admission, he presented skin eruptions with redness and pruritus on hands and feet. Generalized papular erythema was evidenced, upper extremities with diffuse erythematosquamous plaques, palmoplantar keratoderma, so he was evaluated by a dermatologist who diagnosed pityriasis rubra pilaris.

\section{Treatment and outcome:}

rehydrating cream, cetirizine $0.5 \mathrm{mg} / \mathrm{kg} /$ day every two days, and prednisolone $2 \mathrm{mg} /$ $\mathrm{kg} /$ day in the morning. He was discharged after 14 days, the patient presented clinical improvement, but the erythematous lesion persisted on the trunk and extremities. In the evaluation, after three months, the patient did not show the described lesions, evidencing an improvement and clinical resolution of the dermatological problems.

\section{Clinical relevance:}

We report a patient with pityriasis rubra piloris associated with a post-infection by SARS-CoV-2 that had not been described before. 
Conflicts of interest:

The authors declare that they have no conflict of interest

Corresponding author:

Virgilio E Failoc-Rojas, MD, MSc. Universidad San Ignacio de Loyola, Av La Fontana 501. Lima, Perú. Phone: (+51)948845837e-mail: virgiliofr@ gmail.com

\section{Resumen}

\section{Descripción del caso:}

Niño 32 meses de vida, con IgG positivo para SARS-CoV-2, acude al servicio de emergencia por presentar lesiones dermatológicas.

\section{Hallazgos clínicos:}

Cuatro días antes del ingreso presentó erupciones en la piel, con enrojecimiento y prurito en manos y pies. Se evidenció eritema papular generalizado, extremidades superiores con placas eritematoescamosas difusas, queratodermia palmo-plantar por lo que es evaluado por dermatólogo quien diagnostica pitiriasis rubra pilaris.

\section{Tratamiento y resultado:}

Crema rehidratantes, cetirizina $0.5 \mathrm{mg} / \mathrm{kg} / \mathrm{día}$ cada 2 días y prednisolona $2 \mathrm{mg} / \mathrm{kg} / \mathrm{día}$ por la mañana. Fue dado de alta a los 14 días, el paciente presenta mejora clínica, pero aún persiste la lesión eritematosa en tronco y extremidades. En la evaluación a los tres meses el paciente no mostró las lesiones descritas, evidenciando una mejoría y resolución clínica de los problemas dermatológicos.

\section{Relevancia clínica:}

Se reporta un paciente con afectación por pitiriasis rubra piloris asociado a una postinfección por SARS-CoV-2 que no se había descrito antes.Introduction

\section{Introduction}

The disease, coronavirus disease 2019 (COVID-19) caused by SARS-CoV-2 has a broad tropism for different host cells which allows it to produce cardiovascular, neurological, and endocrine complications ${ }^{1-3}$. The most frequent postinfectious symptoms reported in COVID-19 are myalgias, intense fatigue, fever, shortness of breath, chest tightness, tachycardia, headaches, and anxiety ${ }^{4}$.

In dermatology, pressure lesions, contact dermatitis, pruritus, pressure urticaria, and exacerbation of preexisting skin diseases, such as seborrheic dermatitis and acne, have been described ${ }^{5}$. Other cases have reported petechial rash similar to dengue ${ }^{6}$ and varicella-like rash as a specific cutaneous manifestation associated with COVID-19 ${ }^{7}$, which demonstrates the association of this disease with different cutaneous manifestations.

Pityriasis rubra pilaris (a rare disorder with an estimated $0.03 \%$ of cases in all dermatological consultations, being frequent in the pediatric population and affecting both sexes equally ${ }^{8}$. It causes a yellowish hyperkeratosis of the skin, appearing on the trunk, limbs, and, in particular, the palms of the hands and soles of the feet, often with the presence of erythematosquamous plaques of variable evolution, chronic and relapsing; usually benign and exceptionally fatal ${ }^{9}$. Due to the importance of the cutaneous manifestations observed in COVID-19 and the presence of a poorly reported pathology, we report the case of a patient with pityriasis rubra pilaris in a child after infection with SARS-COV-2. 


\section{Case report}

32-month-old male patient, of mixed race, who is brought by the mother to the emergency department for presenting pruritus and skin lesions to rule out acute toxicity. Four days before admission, the child had presented skin rashes, with redness and itching in hands and feet, but then it spread to the whole body including the face, so he was taken to primary care where doctors diagnosed in a first evaluation, urticaria due to intoxication of unknown origin, which was treated with antihistamines, and in a second evaluation the diagnostic presumption was scalded skin syndrome by Staphylococcus aureus so he was referred to a referral hospital in Lambayeque.

On admission to the hospital emergency room, the child weighed $15 \mathrm{~kg}$ (85th percentile for sex and age), had a respiratory rate of 20 breaths/minute, alert and awake conscious, and was afebrile, with no toxic appearance, no visible niedema. Physical examination revealed generalized erythema, follicular papules, and progressive non-painful desquamative exanthem on hands, feet, genitalia, and periorificial areas, with pruritus.

Laboratory examinations showed leukocytosis $\left(15,140 / \mathrm{mm}^{3}\right)$, with a differential formula of segmented $41 \%$, cay $1 \%$, eosinophils $5 \%$, lymphocytes $53 \%$; platelets within normal range $(378,000$ $\left./ \mathrm{mm}^{3}\right)$; hemoglobin, $12.8 \mathrm{~g} / \mathrm{dL}$; C-reactive protein, $12 \mathrm{mg} / \mathrm{L}$; urea, $29.9 \mathrm{mg} / \mathrm{dL}$, creatinine, $0.7 \mathrm{mg} /$ dL; TGP, $73.5 \mathrm{u} / \mathrm{L}$; TGO $75.2 \mu / \mathrm{L}$, triglycerides $71.7 \mathrm{mg} / \mathrm{dL}$, prothrombin time $12 \mathrm{sec}$, serology for parvovirus B19 immunoglobulin (Ig) M negative. Two rapid tests for SARS COV-2 were performed, both IgM negative and IgG positive; the child did not undergo nasal swabbing.

In the background it was determined that he comes from the district of Motupe in Lambayeque-Peru, with no medical history of importance, lives in a rented house of noble material (brick and cement) with 5 rooms and complete basic sanitation services. The mother reported that the child was born at full term, without complications during gestation or delivery, and that the child was fully vaccinated according to his age. Two months before admission, his parents presented a case of acute respiratory infection; however, the patient never presented symptoms and the family did not test for COVID-19.

With these findings and the family epidemiological history, the patient was defined as postinfected with COVID-19. Due to the diagnostic suspicion of Staphylococcus aureus scalded skin, the patient was hospitalized for intravenous treatment and exhaustive evaluation and treatment with oxacillin IV $100 \mathrm{mg} / \mathrm{kg} /$ day every 6 hours a day was started.

In the medical evaluation of the following days, a clinically favorable evolution of the patient was determined, with slight improvement, stable vital signs, good oral tolerance, afebrile, so it is requested to continue with antibiotic treatment and interconsultation is requested for evaluation by the dermatologist.

The evaluation by the dermatologist, performed on the seventh day of hospitalization, describes the presence of diffuse erythematosquamous plaques of cephalocaudal evolution, follicular hyperkeratosis, and palmoplantar keratoderma, with areas of healthy skin. A clinical diagnosis of generalized papulodescamativa disease were made, compatible with pityriasis rubra pilaris (Figure 1). Pathologies such as psoriasis, seborrheic dermatitis, erythrokeratoderma, follicular eczema, ichthyosis, frinoderma, and atypical keratosis pilaris were ruled out, therefore oxacillin was withdrawn, and cleaning with glycerin soap, rehydrating cream, cetirizine $0.5 \mathrm{mg} / \mathrm{kg} /$ day every 2 days, and prednisolone $2 \mathrm{mg} / \mathrm{kg} / \mathrm{day}$ in the morning where indicated, as well as hospital discharge due to clinical improvement. At the 14-day follow-up evaluation, the patient showed clinical improvement, but the erythematous lesion persisted on the trunk and extremities. At the evaluation after three months, the patient did not show the described lesions, evidencing an improvement and clinical resolution of the dermatological problems. 


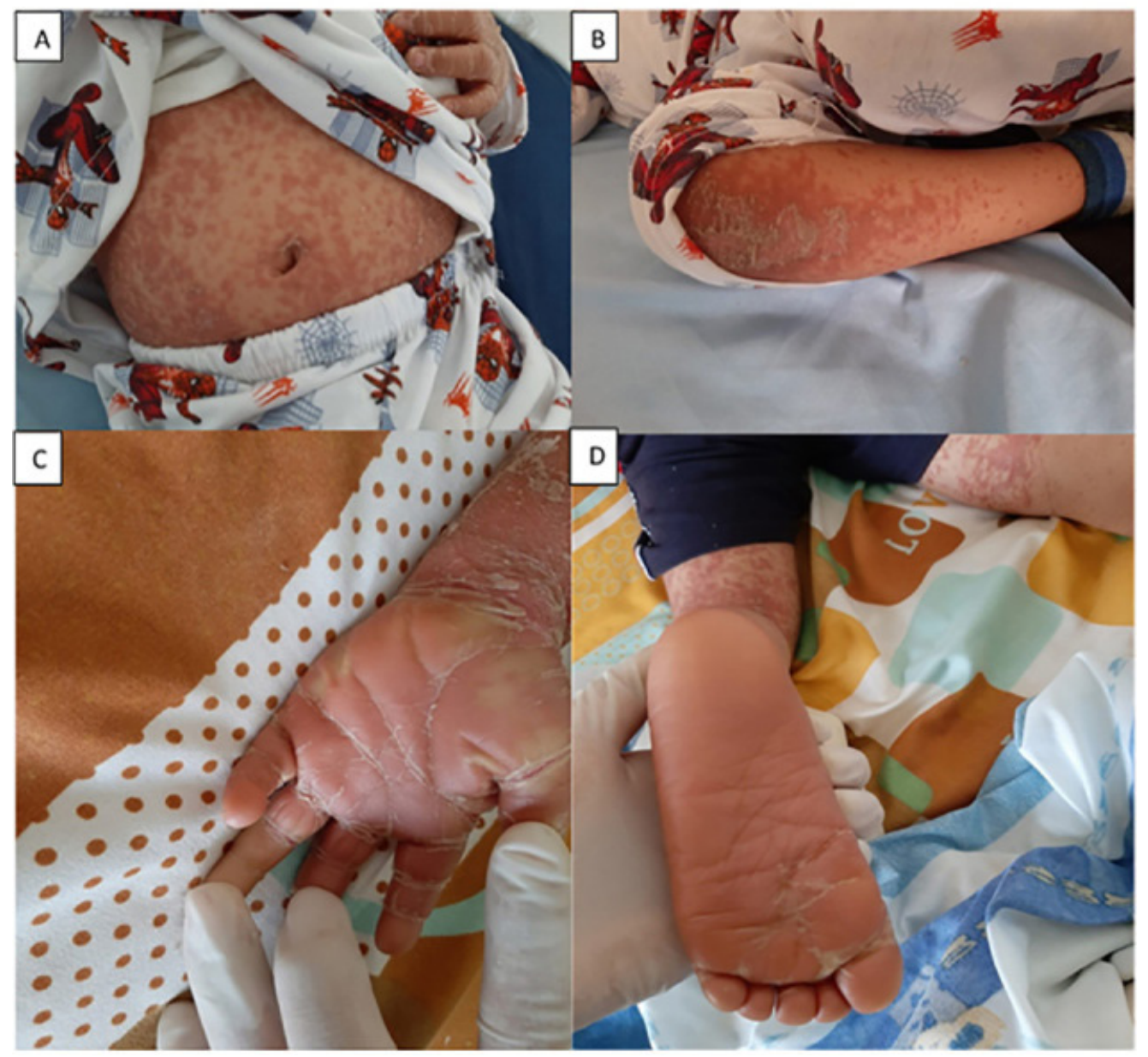

Figure 1. Manifestations of Pityriasis rubra pilaris post-infection with COVID-19. A. Generalized papular erythema, visible on the abdomen $B$. upper extremities with diffuse erythematous scaly plaques $C$ and $D$. Erythematous and scaly papules involving palms and feet describing palmoplantar keratoderma and lamellar hyperkeratosis on hands and feet. The evolution was cephalo-caudal

\section{Discussion}

There are reports that $20.4 \%$ of patients with COVID-19 present cutaneous manifestations in the form of erythematous rash, urticaria, and vesicles resembling chickenpox mainly on the trunk with little or no pruritus; these cutaneous lesions were not related to the severity of the disease ${ }^{10}$.

Dermatological manifestations in COVID-19 have been grouped by morphological patterns, which in turn can predict their evolution. Thus, the lesions can be classified into two large groups according to the pathogenic mechanism: in the first, with clinical features similar to viral exanthem, such as an immune response to viral nucleotides; and in the second, eruptions secondary to consequences caused by COVID-19, especially vasculitis and thrombotic vasculopathy ${ }^{11}$.

Acute post-infectious pityriasis rubra pilaris is a variant of the juvenile form of pityriasis rubra pilaris (Griffiths type III) characterized by the absence of family history, acute course related to a previous febrile episode and good prognosis ${ }^{12}$. Clinically it may mimic other superantigenmediated diseases, such as scarlatiniform rashes or staphylococcal scald syndrome; however, its histology and treatment are different ${ }^{13}$. The exact etiology and pathogenesis of pityriasis rubra pilaris are still unknown. Previously, vitamin A deficiency was postulated as one of the causes of pityriasis rubra pilaris, but it is now known to be sensitive to alitretinoin, isotretinoin, etretinate and vitamin A; furthermore, viral or bacterial infections are recognized as the main antecedents ${ }^{14}$. 
In the case presented, the patient had a history of SARS-COV-2 infection with mild manifestations of the disease and positive serology. In this regard, there are some reports involving viral infectious agents as triggers of pityriasis rubra pilaris. Thus, it has been associated with Herpes Simplex infection ${ }^{15}$, and varicella zoster ${ }^{16}$, both viral infections with favorable prognosis. In contrast, the association with poor prognosis due to infection by the human immunodeficiency virus (HIV) is described, which is classified as pityriasis rubra pilaris type VI and therefore it is advisable to perform a rapid test for the detection of the virus in these cases ${ }^{8}$.

The latency period from COVID-19 infection to the appearance of dermatological lesions in this report is approximately two months; however, it is worth mentioning that due to the idiosyncrasy of the population, they usually seek medical attention in advanced stages. Some dermatological manifestations related to COVID-19 such as maculopapular rash, urticaria, vesicular eruptions appeared in the asymptomatic period; however, erythema multiforme lesions appeared 20 days after the onset of COVID-19 symptoms ${ }^{17}$. Regarding the association with other viral infections and dermatological lesions, the latency time has not been reported because they were incidental findings ${ }^{15,16}$.

In our patient, pityriasis rubra pilaris variant type III was due to age, absence of family cases, and because it was post-infection. As mentioned before, the resemblance with other diagnoses led to another diagnosis and therapeutic and the poor favorable evolution indicated a reevaluation. The diagnosis of pityriasis rubra pilaris is purely clinical, and the experience in the evaluation by the dermatologist when examining the patient's lesions, and ruling out other apparent causes, determined this diagnosis.

The finding of dermatologic lesions in patients with a recent or previous diagnosis of COVID-19 should be evaluated on time. Dermatologic lesions may be a rare late clinical manifestation of COVID-19 disease, even in patients who do not present with typical respiratory disease ${ }^{18}$.

As of the date of this report, the association of pityriasis rubra pilaris following SARS-CoV-2 infection has not been described, so its notification is important for clinicians and the academic community.

\section{References}

1. Ellul MA, Benjamin L, Singh B, Lant S, Michael BD, Easton A, et al. Neurological associations of COVID-19. Lancet Neurology. 2020;19(9):p767-83. Doi: 10.1016/S1474-4422(20)30221-0.

2. Marazuela M, Giustina A, Puig-Domingo M. Endocrine and metabolic aspects of the COVID-19 pandemic. Rev Endocr Metab Disord. 2020;21(4):495-507. doi: 10.1007/s11154-020-09569-2

3. Pirzada A, Mokhtar AT, Moeller AD. COVID-19 and myocarditis: what do we know so far? CJC Open. 2020;2(4):278-85. doi: 10.1016/j.cjco.2020.05.005

4. Carfi A, Bernabei R, Landi F. Persistent symptoms in patients after acute COVID-19. JAMA. 2020; 324(6): 603-605. doi: 10.1001/jama.2020.12603

5. Darlenski R, Tsankov N. COVID-19 pandemic and the skin: what should dermatologists know? Clin Dermatol. 2020; 38(6): 785-787. doi: 10.1016/j.clindermatol.2020.03.012

6. Joob B, Wiwanitkit V. COVID-19 can present with a rash and be mistaken for dengue. J Am Acad Dermatol. 2020;82(5):e177. doi: 10.1016/j.jaad.2020.03.036.

7. Marzano AV, Genovese G, Fabbrocini G, Pigatto P, Monfrecola G, Piraccini BM, et al. Varicella-like exanthem as a specific COVID-19-associated skin manifestation: Multicenter case series of 22 patients. J Am Acad Dermatol. 2020;83(1):280-285. doi: 10.1016/j.jaad.2020.04.044. 
8. Mancilla-Gudiel PM, Arenas R. Pitiriasis rubra pilar: una revisión. Dermatol Cosmética Médica Quirúrgica. 2020;18(1):53-61.

9. Palencia AB, Ramos TIV. Pitiriasis rubra pilaris: aspectos epidemiológicos y clínicos de 44 casos. Dermatol Rev Mexicana. 2008;52(4):153-9.

10. Recalcati S. Cutaneous manifestations in COVID-19: a first perspective. J Eur Acad Dermatol Venereol. 2020;34(5):e212-e213. doi: 10.1111/jdv.16387.

11. Jimenez-Cauhe J, Ortega-Quijano D, Carretero-Barrio I, Suarez-Valle A, Saceda-Corralo D, MorenoGarcia Del Real C, et al. Erythema multiforme-like eruption in patients with COVID-19 infection: clinical and histological findings. Clin Exp Dermatol. 2020;45(7):892-895. doi: 10.1111/ced.14281.

12. Carvajal C, Acosta A, Álvarez M. Pitiriasis rubra pilaris atípica en pediatría. A propósito de un caso. Arch Pediatr Uruguay. 2017;88(5):279-83.

13. Ferrándiz-Pulido $C$, Bartralot R, Bassas $P$, Bodet $D$, Repiso $T$, Aparicio $G$, et al. Pitiriasis rubra pilaris aguda postinfecciosa: una dermatosis mediada por superantígenos. Actas Dermo-Sifiliográficas. 2009;100(8):706-9.

14. Roenneberg S, Biedermann T. Pityriasis rubra pilaris: algorithms for diagnosis and treatment. J Eur Acad Dermatol Venereol. 2018;32(6):889-898. doi: 10.1111/jdv.14761.

15. Williams A, George A, Thomas EA, Koshy JM. Pityriasis rubra pilaris type 6: A case report in an AIDS patient. Indian J Sex Transm Dis AIDS. 2020; 41(1): 100-101. doi: 10.4103/ijstd.IJSTD_120_15

16. Ertam I, Sezgin AO, Kazandi A, Dereli T, Unal I. A case of juvenile pityriasis rubra pilaris: could varicella be an aetiological agent? Clin Exp Dermatol. 2009;34(8):e1012-3. doi: 10.1111/j.1365-2230.2009.03678.x.

17. Gül Ü. COVID-19 and dermatology. Turk J Med Sci. 2020;50(8):1751-1759. doi: 10.3906/sag-2005-182.

18. Gisondi P, Plaserico S, Bordin C, Alaibac M, Girolomoni G, Naldi L. Cutaneous manifestations of SARSCoV-2 infection: a clinical update. J Eur Acad Dermatol Venereol. 2020; 34(11):2499-2504. doi: 10.1111/jdv.16774. 